\title{
BIBLIOGRAPHY AND REFERENCE SYSTEM
}

\section{Reference system}

Unless otherwise indicated, references to secondary literature are detailed at their first occurrence and subsequently abbreviated.

Where references to published works by Wittgenstein use capital-letter abbreviations, they follow the abbreviations introduced below.

References to items in Wittgenstein's Nachlass follow Georg Henrik von Wright's catalogue or, occasionally, other established systems; the "Big Typescript", for example, is referred to by "TS 213" (the typescript with the number 213 in the von Wright catalogue) or by "the Big Typescript".

The von Wright catalogue was first published in G.H. von Wright: "The Wittgenstein Papers", in The Philosophical Review 78, pp. 483-503 (Ithaca, USA, 1969). Revised versions were published in G.H. von Wright: "The Wittgenstein Papers" in Wittgenstein, pp. 35-62 (Oxford: Basil Blackwell, 1982), and, in German, in G.H. von Wright: "Wittgensteins Nachlaß" in Wittgenstein, tr. Joachim Schulte, pp. 45-76 (Frankfurt am Main: Suhrkamp, 1986).

The latest complete revised versions of the von Wright catalogue are to be found in Ludwig Wittgenstein: Philosophical Occasions, ed. James C. Klagge and Alfred Nordmann, pp. 480-506 (Indianapolis and Cambridge, MA: Hackett, 1993), and in Wittgenstein's Nachlass: The Bergen Electronic Edition, ed. Wittgenstein Archives at the University of Bergen (Oxford: OUP, 2000). 


\section{Editions of works by Wittgenstein cited or referred to in this volume}

The following bibliography lists editions of Wittgenstein's works ("works" is understood in a broad sense, including correspondence and lecture and conversation notes), cited or referred to in this volume. It is partly based on the comprehensive bibliographies in Michael Biggs and Alois Pichler: Wittgenstein: Two Source Catalogues and a Bibliography: Catalogues of the Published Texts and of the Published Diagrams, each Related to its Sources, Working Papers from the Wittgenstein Archives at the University of Bergen no. 7 (Bergen, 1993), and Alois Pichler: Wittgensteins Philosophische Untersuchungen: Vom Buch zum Album, Studien zur Österreichischen Philosophie vol. 36, ed. Rudolf Haller (Amsterdam and New York: Rodopi, 2004).

\section{Single items}

The editions are listed with capital-letter abbreviations and in chronological order of first publication of the work.

TLP "Logisch-philosophische Abhandlung". In: Annalen der Natur- und Kulturphilosophie 14, pp. 184-262 (Leipzig, 1921).

Tractatus Logico-Philosophicus. Tr. C.K. Ogden and F.P. Ramsey. International Library of Psychology, Philosophy and Scientific Method. London: Kegan Paul, Trench, Trubner, 1922.

Tr. C.K. Ogden and F.P. Ramsey. London: Kegan Paul, Trench, Trubner \& Co., LTD / New York: Harcourt, Brace \& Co, 1933.

Tr. D.F. Pears and B.F. McGuinness. International Library of Philosophy and Scientific Method. London: Routledge and Kegan Paul, 1961.

German text with an English translation en regard by C.K. Ogden. London: Routledge, 1981.

Logisch-philosophische Abhandlung. Tractatus logico-philosophicus. Kritische Edition. Ed. Brian McGuinness and Joachim Schulte. Frankfurt am Main: Suhrkamp, 1989. 
RLF "Some Remarks on Logical Form". In: Proceedings of the Aristotelian Society Supplementary volume 9, pp. 162-171 (London, 1929).

In: Ludwig Wittgenstein. Philosophical Occasions 1912-1951.

Ed. James C. Klagge and Alfred Nordmann. Indianapolis and Cambridge, MA: Hackett, 1993, pp. 28-35.

PI Philosophical Investigations / Philosophische Untersuchungen. Ed. G.E.M. Anscombe and R. Rhees, tr. G.E.M. Anscombe. Oxford: Basil Blackwell, 1953.

Ed. G.E.M. Anscombe and R. Rhees, tr. G.E.M. Anscombe. Second edition. Oxford: Basil Blackwell, 1958. Repr. $1963,1967$.

Ed. G.E.M. Anscombe and R. Rhees, tr. G.E.M. Anscombe. Revised second edition. Oxford: Basil Blackwell, 1997. Repr. 2000.

Ed. G.E.M. Anscombe and R. Rhees, tr. G.E.M. Anscombe. Third edition [with a revised English translation]. Oxford: Basil Blackwell, 2001.

Philosophische Untersuchungen. Kritisch-genetische Edition. Ed. Joachim Schulte in collaboration with Heikki Nyman, Eike von Savigny and Georg Henrik von Wright. Frankfurt am Main: Suhrkamp, 2001.

MWL G.E. Moore: "Wittgenstein's Lectures in 1930-33". "Part I" in: Mind 63, pp. 1-15 (Edinburgh, 1954), "Part II" in: Mind 63, pp. 289-316 (Edinburgh, 1954), "Part III" in: Mind 64, pp. 1-27 (Edinburgh, 1955), “Two Corrections" in: Mind 64, p. 264 (Edinburgh, 1955).

. In: Philosophical Papers. London: George Allen \& Unwin, 1959, pp. 252-324.

In: Ludwig Wittgenstein. Philosophical Occasions 1912-1951.

Ed. James C. Klagge and Alfred Nordmann. Indianapolis and Cambridge, MA: Hackett, 1993, pp. 45-114.

RFM Remarks on the Foundations of Mathematics / Bemerkungen über die Grundlagen der Mathematik. Ed. G.H. von Wright, R. Rhees and G.E.M. Anscombe, tr. G.E.M. Anscombe. Oxford: Basil Blackwell, 1956.

Remarks on the Foundations of Mathematics. Ed. G.H. von Wright, R. Rhees and G.E.M. Anscombe, tr. G.E.M. Anscombe. Third edition. Oxford: Basil Blackwell, 1978. 
NL "Notes on Logic”. Ed. H.T. Costello. In: The Journal of Philosophy 54, pp. 230-245 (New York, 1957).

. In: Notebooks 1914-1916. Ed. G.H. von Wright and G.E.M. Anscombe, tr. G.E.M. Anscombe. Oxford: Basil Blackwell, 1961, pp. 93-106 (Appendix I).

. In: Notebooks 1914-1916. Ed. G.H. von Wright and G.E.M. Anscombe, tr. G.E.M. Anscombe. Second edition. Oxford: Basil Blackwell, 1979, pp. 93-107 (Appendix I).

BB Preliminary Studies for the "Philosophical Investigations". Generally Known as The Blue and Brown Books. Ed. R. Rhees. Oxford: Basil Blackwell, 1958. Repr. 1964.

1969.

. Ed. R. Rhees. Second edition. Oxford: Basil Blackwell,

NB “Tagebücher 1914-1916”. Ed. G.E.M. Anscombe and G.H. von Wright. In: Schriften Bd. 1. Frankfurt am Main: Suhrkamp, 1960, pp. 85-185.

“Notebooks 1914-1916”. In: Notebooks 1914-1916. Ed. G.H. von Wright and G.E.M. Anscombe, tr. G.E.M. Anscombe. Oxford: Basil Blackwell, 1961, pp. 2-91.

. In: Notebooks 1914-1916. Ed. G.H. von Wright and G.E.M. Anscombe, tr. G.E.M. Anscombe. Second edition. Oxford: Basil Blackwell, 1979, pp. 2-91.

NDM "Aufzeichnungen, die G.E. Moore in Norwegen nach Diktat niedergeschrieben hat / Notes dictated to G.E. Moore in Norway". Ed. G.E.M. Anscombe and G.H. von Wright, tr. Günther Patzig and Eberhard Bubser. In: Schriften Bd. 1. Frankfurt am Main: Suhrkamp, 1960, pp. 226-253.

"Notes dictated to G.E. Moore in Norway". In: Notebooks 19141916. Ed. G.H. von Wright and G.E.M. Anscombe, tr. G.E.M. Anscombe. Oxford: Basil Blackwell, 1961, pp. 107-118.

In: Notebooks 1914-1916. Ed. G.H. von Wright and G.E.M. Anscombe, tr. G.E.M. Anscombe. Second edition. Oxford: Basil Blackwell, 1979, pp. 108-119 (Appendix II).

434 | Wittgenstein: The Philosopher AND his Works 
PR Philosophische Bemerkungen. Ed. Rush Rhees. Oxford: Basil Blackwell, 1964.

. Ed. Rush Rhees, tr. Raymond Hargreaves and Roger White. Oxford: Basil Blackwell, 1975.

. Ed. Rush Rhees, tr. Raymond Hargreaves and Roger White. Chicago: The University of Chicago Press, 1975.

PLP F. Waismann: The Principles of Linguistic Philosophy. Ed. R. Harré. London: Macmillan, 1965.

LC Lectures and Conversations on Aesthetics, Psychology and Religious Belief. Ed. Cyril Barrett. Oxford: Basil Blackwell, 1966.

Z Zettel / Zettel. Ed. G.E.M. Anscombe and G.H. von Wright, tr. G.E.M. Anscombe. Oxford: Basil Blackwell, 1967.

GB "Bemerkungen über Frazers The Golden Bough". Ed. R. Rhees. In: Synthese 17, pp. 233-253 (Dordrecht, Holland, 1967).

WVC Ludwig Wittgenstein und der Wiener Kreis. Ed. Brian McGuinness. Oxford: Basil Blackwell, 1967.

Ludwig Wittgenstein and the Vienna Circle. Conversations recorded by Friedrich Waismann. Ed. Brian McGuinness, tr. Joachim Schulte and Brian McGuinness. Oxford: Basil Blackwell, 1979.

CPE Paul Engelmann: "Briefe von Wittgenstein / Letters from Wittgenstein". In: Letters from Ludwig Wittgenstein. With a Memoir. Ed. B.F. McGuinness, tr. L. Furtmüller. Oxford: Basil Blackwell, 1967, pp. 259.

OC On Certainty / Über Gewißheit. Ed. G.E.M. Anscombe and G.H. von Wright, tr. Denis Paul and G.E.M. Anscombe. Oxford: Basil Blackwell, 1969.

PG Philosophische Grammatik. Ed. Rush Rhees. Oxford: Basil Blackwell, 1969. well, 1974.

. Ed. Rush Rhees, tr. Anthony Kenny. Oxford: Basil BlackEd. Rush Rhees, tr. Anthony Kenny. Berkeley: University of California Press, 1974.

EPB "Eine Philosophische Betrachtung". Ed. R. Rhees, tr. Petra von Morstein. In: Schriften Bd. 5. Frankfurt am Main: Suhrkamp, 1970, pp. 117-282.

BIBLIOGRAPHY AND REFERENCE SYSTEM | 435 
PT Prototractatus. An early version of Tractatus Logico-Philosophicus. Ed. B.F. McGuinness, T. Nyberg and G.H. von Wright, tr. D.F. Pears and B.F. McGuinness. London: Routledge and Kegan Paul, 1971.

. Ed. B.F. McGuinness, T. Nyberg and G.H. von Wright, tr. D.F. Pears and B.F. McGuinness. Ithaca, NY: Cornell University Press, 1971.

LFM Wittgenstein's Lectures on the Foundations of Mathematics: Cambridge, 1939. Ed. Cora Diamond. Sussex: Harvester Press, 1976.

CV Vermischte Bemerkungen. Ed. Georg Henrik von Wright in collaboration with Heikki Nyman. Frankfurt am Main: Suhrkamp, 1977.

Culture and Value / Vermischte Bemerkungen. Ed. G.H. von Wright in collaboration with Heikki Nyman, tr. Peter Winch. Oxford: Basil Blackwell, 1980.

. Ed. G.H. von Wright in collaboration with Heikki Nyman, revised edition of the text Alois Pichler, tr. Peter Winch. Oxford: Basil Blackwell, 1998.

AWL Wittgenstein's Lectures: Cambridge, 1932-1935. Ed. Alice Ambrose. Oxford: Basil Blackwell, 1979.

LWL Wittgenstein's Lectures: Cambridge, 1930-1932. Ed. Desmond Lee. Oxford: Basil Blackwell, 1980.

RPP Remarks on the Philosophy of Psychology / Bemerkungen über die Philosophie der Psychologie. Vol. 1. Ed. G.E.M. Anscombe and G.H. von Wright, tr. G.E.M. Anscombe. Oxford: Basil Blackwell, 1980.

Vol. 2. Ed. G.H. von Wright and Heikki Nyman, tr. C.G. Luckhardt and Maximilian A.E. Aue. Oxford: Basil Blackwell, 1980.

CMD M.O'C. Drury: “Conversations with Wittgenstein”. In: Recollections of Wittgenstein. Ed. R. Rhees. Oxford: Basil Blackwell, 1981, pp. 112189.

. In: Recollections of Wittgenstein. Ed. R. Rhees. Revised edition. Oxford: Basil Blackwell, 1984, pp. 97-171, 218-225. 
LW Last Writings on the Philosophy of Psychology / Letzte Schriften über die Philosophie der Psychologie. Vol. 1. Ed. G.H. von Wright and Heikki Nyman, tr. C.G. Luckhardt and Maximilian A.E. Aue. Oxford: Basil Blackwell, 1982.

Vol. 2. Ed. G.H. von Wright and Heikki Nyman, tr. C.G. Luckhardt and Maximilian A.E. Aue. Oxford: Basil Blackwell, 1992.

PH "Philosophie". Ed. Heikki Nyman. In: Revue Internationale de Philosophie 43, pp. 172-203 (Brussels, 1989).

In: Ludwig Wittgenstein. Philosophical Occasions 1912-1951. Ed. James C. Klagge and Alfred Nordmann. Indianapolis and Cambridge, MA: Hackett, 1993, pp. 158-199.

CCL Cambridge Letters. Correspondence with Russell, Keynes, Moore, Ramsey and Sraffa. Ed. Brian McGuinness and G.H. von Wright. Oxford, U.K. / Cambridge, MA: Blackwell, 1995.

DB Denkbewegungen: Tagebücher 1930-1932, 1936-1937 (MS 183). Vol. 1: Normalisierte Fassung. Ed. Ilse Somavilla. Innsbruck: Haymon, 1997.

Vol. 2: Diplomatische Fassung. Ed. Ilse Somavilla. Innsbruck: Haymon, 1997.

Movements of Thought: Diaries 1930-1932, 1936-1937. In: Ludwig Wittgenstein. Public and Private Occasions. Ed. James C. Klagge and Alfred Nordmann, tr. Alfred Nordmann. Lanham: Rowman and Littlefield, 2003, pp. 3-255.

BEE Wittgenstein's Nachlass: The Bergen Electronic Edition. Ed. Wittgenstein Archives at the University of Bergen. Oxford: Oxford University Press, 2000. (electronic)

VOW Ludwig Wittgenstein and Friedrich Waismann: The Voices of Wittgenstein. The Vienna Circle. Ed. Gordon Baker, tr. Gordon Baker, Michael Makkert, John Connolly and Vasilis Politis. London and New York: Routledge, 2003.

ICE Briefwechsel: Innsbrucker elektronische Ausgabe. Ed. Monika Seekircher, Brian McGuinness, Anton Unterkircher. Charlottesville: InteLex Corporation, 2004. ${ }^{\text {(electronic) }}$ 


\section{Schriften (Frankfurt am Main: Suhrkamp 1960-I982)}

- Band 1. Tractatus logico-philosophicus; Tagebücher 1914-1916; Aufzeichnungen über Logik / Notes on Logic; Aufzeichnungen, die G.E. Moore in Norwegen nach Diktat niedergeschrieben hat / Notes dictated to G.E. Moore in Norway; Auszüge aus Wittgensteins Briefen an Russell, 1912-20 / Extracts from Wittgenstein's letters to Russell, 1912-20; Philosophische Untersuchungen. 1960.

- Band 2. Philosophische Bemerkungen; Aus F. Waismanns stenographischer Abschrift von Reden und Gesprächen Wittgensteins zwischen Dezember 1929 und September 1931. 1964.

- Band 3. Wittgenstein und der Wiener Kreis; Wittgenstein an Ramsey. 1967.

- Band 4. Philosophische Grammatik. 1969.

- Band 5. Das Blaue Buch, Eine Philosophische Betrachtung, Zettel. 1970.

- Band 6. Bemerkungen über die Grundlagen der Mathematik. 1974.

- Band 7. Wittgensteins Vorlesungen über die Grundlagen der Mathematik: Cambridge, 1939. 1978.

- Band 8. Bemerkungen über die Philosophie der Psychologie. 1982.

\section{Werkausgabe (Frankfurt am Main: Suhrkamp 1984)}

- Band 1. Tractatus logico-philosophicus; Tagebücher 1914-1916; Aufzeichnungen über Logik; Aufzeichnungen, die G.E. Moore in Norwegen nach Diktat niedergeschrieben hat; Philosophische Untersuchungen.

- Band 2. Philosophische Bemerkungen.

- Band 3. Ludwig Wittgenstein und der Wiener Kreis.

- Band 4. Philosophische Grammatik.

- Band 5. Das Blaue Buch, Eine Philosophische Betrachtung (Das Braune Buch).

- Band 6. Bemerkungen über die Grundlagen der Mathematik.

- Band 7. Bemerkungen über die Philosophie der Psychologie, Letzte Schriften über die Philosophie der Psychologie.

- Band 8. Bemerkungen über die Farben, Über Gewißheit, Zettel, Vermischte Bemerkungen. 


\section{Wiener Ausgabe / Vienna Edition}

\section{(ed. Michael Nedo, Wien and New York: Springer 1993-)}

- $\quad$ Einführung / Introduction. 1993.

- Band 1. Philosophische Bemerkungen. 1994.

- Band 2. Philosophische Betrachtungen, Philosophische Bemerkungen. 1994.

- Band 3. Bemerkungen, Philosophische Bemerkungen. 1995.

- Band 4. Bemerkungen zur Philosophie, Bemerkungen zur philosophischen Grammatik. 1995.

- Band 5. Philosophische Grammatik. 1996.

- $\quad$ Band 8. Synopse der Manuskriptbände V bis X. 2000.

- Band 11. “The Big Typescript”. 2000.

- Apparatus. Konkordanz zu den Bänden 1-5. 1997.

- Apparatus. Register zu den Bänden 1-5. 1998.

\section{Intelex Past Masters database editions}

\section{(Clayton, GA: InteLex Corporation $1989 \mathrm{ff}$ )}

- Wittgenstein: The Published Works

- Wittgenstein: Collected Works

- Wittgenstein: Gesamtbriefwechsel/Complete Correspondence

- Wittgenstein: Letters and Lectures

- Wittgenstein: Nachlass

- Wittgenstein: Tagebücher und Briefe 